\title{
HAMBATAN PENDIDIKAN KARAKTER \\ DI SEKOLAH ISLAM TERPADU \\ (STUDI KASUS SDIT AL HASNA KLATEN)
}

\author{
Danu Eko Agustinova \\ Program Studi Pendidikan Sejarah \\ Fakultas Ilmu Sosial Universitas Negeri Yogyakarta
}

\begin{abstract}
ABSTRAK
Penelitian ini bertujuan untuk menganalisis hambatan yang dialami dalam menanamkan nilai-nilai karakter kepada peserta didik di Sekolah Islam Terpadu. Dimana pada model sekolah ini, pendidikan karakter telah dilaksanakan lebih awal sejak kelahiran model sekolah tersebut. Penelitian ini dilakukan di SDIT Al Hasna Klaten. Metode penelitian ini adalah kualitatif deskriptif dengan strategi yang digunakan adalah studi kasus tunggal. Cuplikan yang digunakan dalam penelitian ini adalah purposive sampling dengan criterion-based selection. Pengumpulan data dilakukan dengan observasi langsung, wawancara mendalam, dan pencatatan dokumen. Validasi data dilaksanakan dengan trianggulasi. Analisis data yang digunakan adalah model analisis interaktif, yaitu pengumpulan data, reduksi data, sajian data dan penarikan kesimpulan. Hasil penelitian ini menyimpulkan bahwa Hambatan yang dialami dalam proses penanaman karakter berasal dari dalam dan dari luar. Hambatan dari dalam meliputi pendidik yang kurang bisa memahami karakteristik masing-masing siswa. Kurangnya sarana penunjang dalam kegiatan pembelajaran. Selain itu, sistem full day itu sendiri yang ternyata memiliki beberapa kelemahan. Sedangkan, hambatan dari luar adalah kurang partisipasi aktif orang tua dalam proses penanaman karakter.
\end{abstract}

Kata Kunci: Pendidikan Karakter, Hambatan, SDIT Al Hasna. 
PENDAHULUAN

Penyelenggaraan dan tujuan pendidikan di Indonesia telah diatur dalam sebuah peraturan perundangundangan. Peraturan tersebut adalah Undang-undang Sistem Pendidikan Nasional (UU Sisdiknas) Republik Indonesia (RI) no: 20 tahun 2003 pada bab ke II, pasal 3 yang berbunyi: Pendidikan nasional berfungsi mengembangkan kemampuan dan membentuk watak serta peradaban bangsa yang bermartabat dalam rangka mencerdaskan kehidupan bangsa, yang bertujuan untuk berkembangnya potensi peserta didik agar menjadi manusia yang beriman dan bertaqwa kepada Tuhan Yang Maha Esa, berakhlak mulia, sehat, berilmu, cakap, mandiri, dan menjadi warga negara yang demokratis serta bertanggung jawab.

Berdasarkan UU Sisdiknas tersebut, secara garis besar pendidikan merupakan upaya membentuk suatu lingkungan untuk siswa yang dapat merangsang pertumbuhan kemampuankemampuan yang dimilikinya serta akan membawa perubahan yang dikehendaki dalam kebiasaan dan karakternya. Dari tujuan pendidikan nasional tersebut kata kuncinya (keywords) adalah bagaimana pendidikan dapat membentuk karakter para siswa. Ir. Soekarno menyatakan:

Bangsa ini harus
mendahulukan
pembangunan karakter
(character building)
karena character building
inilah yang akan membuat
Indonesia menjadi bangsa
yang besar, maju dan jaya,
serta bermartabat. Jika
character building ini
tidak dilakukan, maka
bangsa Indonesia hanya
akan menjadi bangsa kuli
(Muchlas Samani, 2012:
2).

Bahkan di salah satu hadits menunjukkan betapa penting penanaman akhlak kepada peserta didik: “innama bu'itstu liutammima makaarimal akhlaaq" Sesungguhnya aku diutus hanyalah untuk menyempurnakan akhlak manusia (HR. Malik).

Wacana pendidikan karakter di Indonesia akhir-akhir ini semakin menghangat. Hal ini dilandasi kenyataan, betapa 
pendidikan yang selama ini ada salah pengelolaan dan keliru arah. Pendidikan saat ini belum mampu melahirkan pribadi-pribadi unggul, yang jujur, bertanggung jawab, berakhlak mulia, bertakwa, serta manusiawi. Penyimpangan arah ini menjadi hambatan dalam usaha mewujudkan pembangunan karakter bagi seluruh warga negara melalui pendidikan. Dunia pendidikan belum bisa memberikan alokasi yang memadai bagi tumbuhnya nilai-nilai kebajikan (virtues). Pendidikan hanya mampu melahirkan ahli ilmu pengetahuan (agama, matematika, biologi, ekonomi, dan teknologi) tetapi miskin etika serta integritas.

Di tengah carut-marutnya permasalahan karakter di dunia pendidikan bangsa ini, sebetulnya banyak muncul ide pendidikan yang inovatif-kreatif serta baru dari sekelompok anak bangsa. Mereka tidak hanya pandai menghujat, namun juga menawarkan penyajian yang nyata. Sebut saja kelahiran Sekolah Islam Terpadu (SIT). SIT ini terdiri dari SDIT (Sekolah Dasar Islam Terpadu), SMPIT (Sekolah Menengah Pertama Islam Terpadu),
SMAIT (Sekolah Menengah Atas Islam Terpadu), bahkan di beberapa Sekolah Islam Terpadu SIT, ada kelas play group (taman bermain) dan tempat penitipan anak. Sekolah ini mempunyai konsep full day (satu hari penuh).

Salah satu SIT yang menerapkannya adalah SDIT Al Hasna. Sekolah Dasar ini terletak di Kabupaten Klaten. Usia sekolah ini baru sekitar tujuh tahun. Usia yang terbilang muda untuk ukuran sebuah sekolah, SDIT Al Hasna telah memiliki nama yang baik di masyarakat. Hal ini membuat tidak sedikit orang tua menyekolahkan anaknya disekolah tersebut. SDIT Al Hasna menawarkan satu model sekolah yang integralistik. SDIT Al Hasna memadukan pendidikan umum dan pendidikan agama dalam satu jalinan kurikulum dalam penyelenggaraannya.

Melalui pendekatan ini, semua bidang studi dan semua kegiatan sekolah tidak pernah lari dari bingkai ajaran serta pesan nilai agama. Pengertian "terpadu" dalam perangkat pendidikan SDIT Al Hasna memiliki arti, Islam yang 
utuh, menyeluruh, bukan terpisahpisah. Keterpaduan dalam hal metode pembelajarannya sehingga dapat mengoptimalkan aspek kognitif (pengetahuan), psikomotorik (keterampilan) dan afektif (sikap) peserta didik. SDIT Al Hasna berusaha mengharmonisasikan pendidikan fikriyah (kemampuan intelektual), ruhiyah (kemampuan emosional), dan jasadiyah (kemampuan fisik).

Di Indonesia pelaksanaan pendidikan karakter saat ini memang dirasakan mendesak. Gambaran situasi dunia pendidikan bahkan masyarakat di Indonesia menjadi dorongan pokok pengarusutamaan (mainstreaming) penerapan pendidikan karakter di Indonesia. Belum hilang dalam ingatan terhadap tawuran antar pelajar SMAN 6 dan SMAN 70, yang menyebabkan seorang siswa SMA 6 tewas, dilanjutkan dua hari berselang tawuran pelajar antara SMA Yayasan Karya 66 (Yakhe) dengan SMK Kartika Zeni. Semua terjadi di Jakarta. Menurut, data Komisi Nasional Perlindungan Anak (KPAI) merilis jumlah tawuran pelajar tahun ini sebanyak
339 kasus dan memakan korban jiwa 82 orang (Tribun Jogja, 10/09/2012: 1).

Fenomena tawuran pelajar yang semakin marak akhir-akhir ini tentu masalah yang tidak boleh dibiarkan berlarut-larut. Tawuran ini bukanlah tawuran yang biasa saja. Perkelahian beramai-ramai tersebut bukan dengan tangan kosong atau mengandalkan kekuatan, melainkan sudah menggunakan barang-barang atau senjata berbahaya lainnya, dan telah mengarah ke tindakan kriminal karena menelan korban jiwa. Tidak berhenti disitu, rusaknya moral bangsa juga dapat dilihat dari korupsi yang semakin merajalela. Berdasarkan Indeks Persepsi Korupsi (IPK) yang dirilis oleh Tranparency International Indonesia (TII) Tahun 2012 diperoleh data:

IPK Indonesia skornya 32 menempati urutan ke-118 dari 176 negara. Posisi itu turun ketimbang tahun sebelumnya yang berada di peringkat 110. Di kawasan Asia Tenggara, posisi IPK Indonesia masih kalah dibandingkan 


$\begin{array}{lr}\text { negara-negara } & \text { seperti } \\ \text { Singapura, } & \text { Brunei } \\ \text { Darussalam, } & \text { Malaysia, } \\ \text { Thailand dan } & \text { Filipina } \\ \text { (Media } & \text { Indonesia, } \\ \text { 10/12/2012: 1). } & \end{array}$

Masalah-masalah praktik pendidikan karakter dan masalah perilaku moral di berbagai jenjang pendidikan sebagaimana diuraikan di atas dapat menjelaskan dan meyakinkan pentingnya menghidupkan kembali pendidikan karakter. Berangkat dari dua gejala di atas, peneliti tertarik untuk melakukan penelitian. SDIT yang menjadi bagian dari SIT memegang peranan penting dalam pendidikan karakter. Di SDIT penanaman dan pengembangan pendidikan karakter sudah diterapkan sejak lama. Bahkan sejak berdirinya model sekolah tersebut, yaitu sekitar tahun 1993, para komponen di dalamnya sudah mempunyai konsep dan perangkat yang jelas mengenai pendidikan karakter bagi para peserta didiknya. Akan tetapi pelaksanaan pendidikan karakter di Sekolah Islam Terpadu mengalami beberapa kendala atau hambatan dari situlah peneliti tertarik untuk melakukan penelitian

\section{PEMBAHASAN}

Dalam proses penanaman karakter kepada peserta didik ustadzustadzah SDIT Al Hasna mengalami beberapa hambatan. Dari mulai kontrol terhadap para siswa di luar sekolah sangat sulit. Hal ini merupakan permasalahan tersendiri dalam rangka penanaman karakter bagi peserta didik. Peran serta keluarga dan masyarakat dalam proses pembentukan karakter anak masih rendah. Padahal, kebiasaan di lingkungan keluarga dan masyarakat ikut berpengaruh besar dalam pembentukan karakter anak. Resiko dari gejala diatas, ustadz-ustadzah mempunyai tanggung jawab yang berat dalam mengawal penanaman karakter pada diri siswa. Padahal sekolah hanya memiliki waktu yang sangat sedikit dalam hal tersebut. Dalam setiap kesempatan ustadz-ustadzah harus selalu berusaha menyentuh dan memotivasi peserta didik dengan masalah karakter.

Menurut penulis hambatan lain dan hal tersebut penting dalam penanaman karakter di SDIT Al Hasna adalah sistem pendidikan di sekolah yang sehari penuh (full day school). Full day school merupakan sebutan untuk sekolah-sekolah yang 
menerapkan pembelajaran selama sehari penuh layaknya waktu seorang pekerja. Dalam full day school, setiap siswa diharuskan untuk berada di lingkungan sekolah selama satu hari penuh. Dengan satu hari penuh berada di sekolah, pihak sekolah mengharapkan siswa dapat konsentrasi untuk belajar. Di sekolah biasa, waktu pelajaran maksimal hingga pukul 1-2 siang. Sekolah yang menerapkan sistem full day kurang lebih 8 jam waktu belajarnya dalam sehari, yakni mulai dari jam 07.00 WIB sampai dengan jam 15.30 WIB. Hal ini dikarenakan muatan kurikulum yang banyak yaitu adanya pendidikan umum, pendidikan agama dan keterampilan. Sehingga membutuhkan waktu belajar yang lebih lama.

Banyak keuntungan yang bisa diraih ketika seorang anak belajar di full day school. Akan tetapi, ibarat pepatah, tak ada gading yang tak retak. Ungkapan tersebut juga berlaku bagi sekolah yang menerapkan sistem full day. Berbagai kelebihan yang ada, ternyata sekolah dengan sistem ini pun memiliki beberapa kekurangan. Kekurangan ini juga dapat menjadi penghambat dalam proses penanaman karakter. Berikut ini akan dipaparkan beberapa kelemahan atau kekurangan sistem full day school yang menjadi penghambat proses penanaman karakter.

Satu kerugian yang pasti terlihat dari model full day school adalah hilangnya waktu sang anak untuk bersosialisasi dan bermain dengan lingkungan sekitar. Mereka rela kehilangan waktu bermain dan mengeksplor hal-hal lain yang lebih liar tanpa dibatasi aturan-aturan formal yang seringkali menjemukan bagi anak. Padahal di dunia itu anak sering kali menemukan dan mengembangkan talentanya. Menurut teori Piaget pikiran anak bukanlah suatu kotak yang kosong, sebaliknya anak memiliki sejumlah gagasan tentang dunia fisik dan alamiah, yang berbeda dengan gagasan orang dewasa.

Anak-anak datang ke sekolah dengan gagasan-gagasan mereka sendiri. pada dasarnya anak adalah makhluk yang berpengetahuan yang selalu termotivasi untuk memperoleh pengetahuan. Cara terbaik untuk memelihara motivasi akan pengetahuan ini ialah membiarkan anak untuk secara spontan berinteraksi dengan lingkungan. Pendidikan harus menjamin bahwa pendidikan tidak akan menumpulkan rasa keingintahuan anak dengan 
menyusun suatu kurikulum yang sangat kaku yang merusak irama dan langkah belajar anak itu sendiri.

Menurut Peaget, siswa dalam segala usia secara aktif terlibat dalam proses perolehan informasi dan membangun pengetahuan mereka sendiri. Pengetahuan tidak statis tetapi secara terus menerus tumbuh dan berubah pada saat siswa menghadapi pengalaman-pengalaman baru yang memaksa mereka membangun dan memodifikasi pengetahuan awal mereka. Piaget menjelaskan bahwa anak kecil memiliki rasa ingin tahu bawaan dan secara terus menerus berusaha memahami dunia sekitarnya. Rasa ingin tahu ini menurut Piaget, memotivasi mereka untuk aktif membangun pemahaman mereka tentang lingkungan yang mereka hayati.

Anak-anak akan belajar lebih baik apabila dapat menghadapi lingkungan dengan baik. pendidik harus membantu anak agar dapat berinteraksi dengan lingkungan sebaik-baiknya. Maksudnya, belajar paling baik adalah dengan menemukan (discovery). Artinya di sini adalah agar pembelajaran yang berpusat pada anak berlangsung efektif, guru tidak meninggalkan anak-anak belajar sendiri, tetapi mereka memberi tugas khusus yang dirancang untuk membimbing para siswa menemukan dan menyelesaikan masalah sendiri.

Dengan lamanya waktu belajar di sekolah, anak-anak juga akan banyak kehilangan waktu di rumah dan belajar tentang hidup bersama keluarganya. Sore hari anak-anak akan pulang dalam keadaan lelah dan mungkin tidak berminat lagi untuk bercengkrama dengan keluarga. Ditambah lagi sikap orang tua yang merasa telah membayar mahal untuk menyekolahkan anaknya di sekolah full day, cenderung "pasrah bongkokan" kepada sekolah. Mereka percaya penuh kepada sekolah mengenai masa depan anaknya, tanpa harus repot memikirkan apa yang harus orang tua lakukan untuk buah hatinya. Mereka menganggap bahwa jika anak sudah seharian penuh di sekolah, berarti menjadi tanggung jawab sekolah. Mereka mau nakal atau tidak, bukan urusan mereka. Biarkan sekolah yang menyelesaikan. Padahal, sesungguhnya sekolah terbaik itu ada di dalam rumah dan pada keluarga.

Dengan waktu sekolah yang hampir 9 jam, anak kembali ke rumah pada sore hari. Kondisi tubuh yang letih karena seharian berada di sekolah 
membuat anak malas untuk berinteraksi dengan lingkungannya. Ketika kembali ke rumah, anak lebih memilih berisirahat atau menyelesaikan tugas untuk esok hari dibandingkan bermain dengan teman sebayanya. Keadaan seperti ini akan menyebabkan anak kehilangan kehidupan sosialnya. Orang yang dia temui hanya teman satu sekolah.

Sistem full day ini juga bertentangan dengan teori pembelajaran Lev Vygotsky. Menurut teori Vygotsky, fungsi kognitif berasal dari interaksi sosial masing-masing individu dalam konsep budaya. Vygotsky juga yakin bahwa pembelajaran terjadi saat siswa bekerja menangani tugas-tugas yang belum dipelajari namun tugas-tugas itu berada dalam "zone of proximal development" mereka. Zone of proximal development adalah jarak antara tingkat perkembangan sesungguhnya yang ditunjukkan dalam kemampuan pemecahan masalah secara mandiri dan tingkat kemampuan perkembangan potensial yang ditunjukkan dalam kemampuan pemecahan masalah di bawah bimbingan orang dewasa atau teman sebaya yang lebih mampu. Vygotsky menekankan peranan orang

dewasa dan anak-anak lain dalam memudahkan perkembangan si anak.

Menurut

keterampilan-keterampilan

Vygotsky,

keberfungsian mental berkembang melalui interaksi sosial langsung. Informasi tentang alat-alat, keterampilan-keterampilan dan hubungan-hubungan interpersonal kognitif dipancarkan melalui interaksi langsung dengan manusia. Melalui pengorganisasian pengalamanpengalaman interaksi sosial yang berada di dalam suatu latar belakang kebudayaan ini, perkembangan mental anak-anak menjadi matang.

Aliran psikologi yang dipegang oleh Vygotsky lebih mengacu pada kontruktivisme karena Vygotsky lebih menekankan pada hakikat pembelajaran sosiokultural. Dalam analisisnya, perkembangan kognitif seseorang disamping ditentukan oleh individu sendiri secara aktif, juga ditentukan oleh lingkungan sosial secara aktif. Meskipun pada akhirnya anak-anak akan mempelajari sendiri beberapa konsep melalui pengalaman sehari-hari, Vygotsky percaya bahwa anak akan jauh lebih berkembang jika berinteraksi dengan orang lain. Anak-anak tidak akan pernah mengembangkan 
pemikiran operasional formal tanpa bantuan orang lain.

Anak hasil lulusan full day school pasti akan butuh adaptasi sedikit lama dengan lingkungan sekitar. Karena dia "lupa" bagaimana caranya berinteraksi dengan lingkungan sekitarnya akibat waktunya dihabiskan di sekolah. Padahal, Pendidikan tidak pernah dapat dipisahkan dari keadaan sosial, karena sejatinya para praktisi di pendidikan adalah pelaku sosial. Selain itu, bukankah pada hakekatnya manusia itu makhluk sosial yang membutuhkan sebuah kehidupan bermasyarakat, saling membantu antara satu dengan yang lainnya. Seandainya anak tak terbiasa untuk bergaul dengan sahabat-sahabat mereka, bagaimana mereka bisa hidup bermasyarakat.

Sementara itu, bermain merupakan kodrati setiap anak, bahkan menjadi kebutuhan rohani setiap individu. Bagi siswa, sekolah yang sampai sehari penuh mengurangi waktu mereka untuk bermain dan menyosialisasikan pribadi mereka. Ketika sampai di rumah sudah sore, badan capek, sehingga tidak sempat berkunjung ke rumah teman untuk bermain. Hal tersebut mengakibatkan kurang terlatihnya jiwa sosial terhadap lingkungan rumahnya, karena teman yang dimilikinya hanyalah teman di sekolah. Selain itu, mereka kurang tanggap terhadap lingkungan. Setelah pulang dan sampai di rumah, jarang keluar rumah. Jika keluarpun, jauh dari lingkungan rumah.

Masih berkaitan dengan problem sosialisasi anak hasil lulusan full day school. Perasaan sombong, tinggi hati, rentan terjadi pada anak yang disekolahkan di full day school. Peribahasa "katak dalam tempurung" sangat cocok disematkan pada anak yang bersekolah di full day school. Aroma kompetisi dengan dunia luar jarang dirasakan oleh anak hasil full day school. Hal ini cukup wajar karena memang dalam kesehariannya, dia tidak pernah bergaul dengan orang luar. Dia tidak pernah melihat keluar kotak. Dunianya terbatas pada pagar sekolah dan hanya seluas area sekolah. Meskipun fasilitas yang disediakan cukup mumpuni, kadang-kadang dijumpai anak yang bersekolah di full day school, justru kemampuannya tertinggal dari anak yang bersekolah di sekolah biasa.

\section{KESIMPULAN}

Hambatan yang dialami ustadzustadzah SDIT Al Hasna dalam 
penanaman karakter kepada peserta didik berasal dari faktor internal (dalam) serta factor eksternal (luar). Kendala-kendala tersebut antara lain, dari mulai kontrol terhadap para siswa di luar sekolah lumayan sulit. Di tambah lagi peran keluarga dalam membantu proses penanaman karakter masih kurang. Sering dijumpai keluarga yang lepas tangan dalam mendidik anaknya. Hambatan lain yang menjadi kendala dalam penanaman karakter di SDIT Al Hasna adalah sistem pendidikan di sekolah yang sehari penuh (full day school). Dengan sistem seperti ini anak kehilangan waktu untuk bersosialisasi dan bermain dengan lingkungan sekitar (keluarga dan masyarakat). Padahal di dunia luar (masyarakat) anak sering kali menemukan dan mengembangkan bakat dan talentanya. Ibaratnya sekolah terbaik itu ada di dunia luar seperti di dalam keluarga dan mayarakat.

\section{DAFTAR PUSTAKA}

Arief Furchan. 2011. Pengantar Penelitian Dalam Pendidikan. Yogyakarta: Pustaka Pelajar.

Ary Ginanjar Agustian. 2001. Rahasia Sukses Membangun Kecerdasan Emosi dan Spritual. Jakarta: Arga Publishing.

Dwi Budiyanto. 2011. "Pendidikan Profetik: Membentuk Pribadi
Badan Standar Nasional Pendidikan (BSNP). 2006. Panduan Penyusunan Kurikulum Tingkat Satuan Pendidikan Jenjang Pendidikan Dasar dan Menengah, Jakarta. BSNP.

Balitbang Depdiknas. 2006. Panduan Penilaian Berbasis Kelas. Jakarta: Depdiknas.

Cervone, Daniel. "Personality: Theory and Research". a.b. Aliya Tusyani 2011. Kepribadian (Teori dan Penelitian). Jakarta: Salemba Humanika.

Darmiyati Zuchdi. 2008. Humanisasi Pendidikan, Menemukan Kembali Pendidikan yang Manusiawi. Jakarta: Bumi Aksara. Karakter (Grand Design dan Nilai-nilai Target). Yogyakarta: UNY Press.

------------------. 2011. Pendidikan Karakter dalam Perspektif Teori dan Praktik. Yogyakarta: UNY Press.

Dimyati dan Mudjiono. 2006. Belajar dan Pembelajaran. Jakarta: Rineka Cipta.

Direktorat Jenderal Pendidikan Tinggi Kementerian Pendidikan Nasional, 2010, Draf Grand Design Pendidikan Karakter. Edisi 23 Oktober 2010.

Doni Koesoema A. 2010. Pendidikan Karakter Strategi Mendidik Anak di Zaman Global. Jakarta: Grasindo.

Cerdas dan Berkarakter" hlm. 7892. Dalam Hendra Suguantoro (edt). 
(2011). Pendidikan Profetik Revolusi Manusia Abad 21. Yogyakarta: Educational Center BEM REMA UNY.

E.Koeswara. $1991 . \quad$ Teori-teori Kepribadian (Psikoanalisis, Behaviorisme, Humanistik). Bandung: Eresco.

Fasli Jalal. 2010. Kebijakan Nasional Pembangunan Karakter Bangsa: Tiga Stream Pendekatan. Jakarta: Kemendiknas.
Goble. G. Frank. 2002. Mazhab Ketiga (Psikologi Humanistik Abraham Maslow). Yogyakarta: Kanisius.

H. B. Sutopo. 2006. Metodologi Penelitian Kualitatif (Dasar Teori dan Terapannya dalam Penelitian). Surakarta: UNS Press.

Jarolimek, John \& Parker, Walter C. 1993. Social Studies in Elementary School. (9th ed.). New York: Macmillan Publishing Company. 